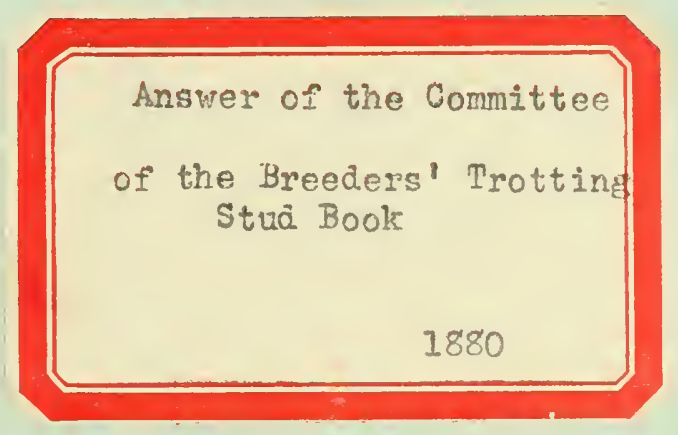




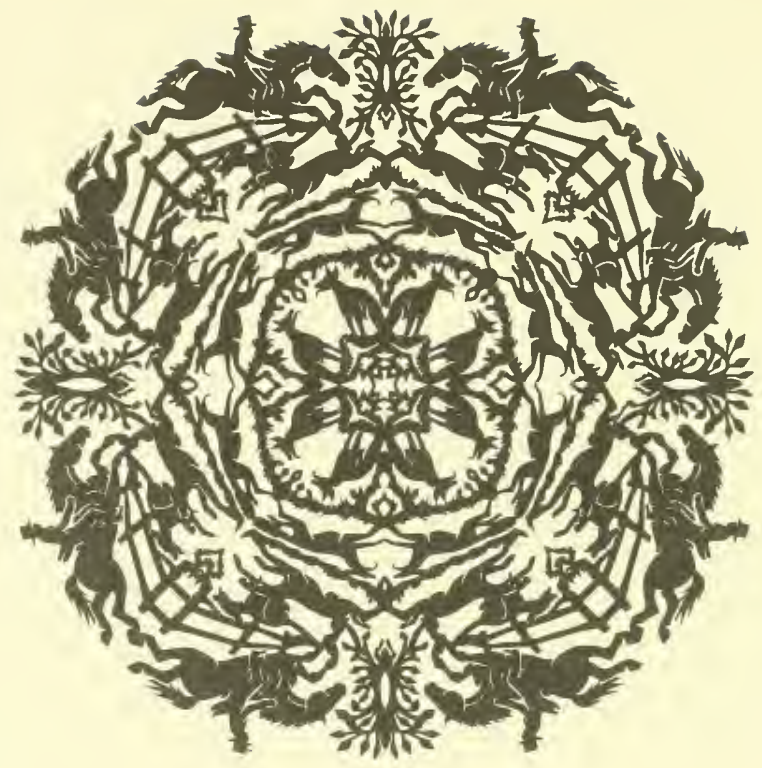

JOHN A.SEAVERNS 


\section{ANSWER OF THE COMMITTEE ON RULES}

OF THE

\section{BRRRERRR' TRONTING STUD BOOK}

TO THE

ADDRESS OF THE EXECUTIVE COMMITTEE

OF THE

NATIONAL ASSOCIATION OF TROTTING HORSE BREEDERS.

FRANKFORT, KY.:

PRINTED AT THE KENTUCKY YEOMAN OFFICE.

MAJOR, JOHNSTON \& BARRETT.

I880. 
Digitized by the Internet Archive in 2009 with funding from

Boston Library Consortium Member Libraries 


\title{
A NSWER
}

OF THE

\section{COMMITTEE ON RULES}

\author{
OF THE
}

\section{BRREDRRS" RROTTING STIUD BOOK}

TO THE

ADDRESS OF THE EXECUTIVE COMMITTEE

OF THE

NATIONAL ASSOCIATION UF TROTTING HORSE BREEDERS.

F R A N K F O R T, KY.

PRINTED AT IHE KENTUCKY YEOMAN OFFICE.

MAJOR, JOHNSTON \& BARRETT.

I 880 . 



\section{A NSWER.}

It is difficult to answer, in a dignified manner, so undignified a document as the Address of the Executive Committee of the National Association of Trotting Horse Breeders; and had it not, by its misrepresentations, directly impeached the fairness of our motives in proposing rules for a Trotting Stud Book, and endeavored to hold our work up to public contempt and ridicule, we would have deemed it the wisest course to pass it by in silence. As it is, we are compelled, by a decent regard for ourselves and the trotting horse inter. est, to give publicity thus to a simple statement of the truth of the case.

And at the very outset let it be borne in mind, that the pamphlet of the National Association purports to be prepared by a Committee appointed by their Executive Committee, and that this Committee presumably consisted of Mr. J. H. Wallace, who is, we believe, in reality the author of this Address, and should be known as such. The National Association of Trotting Horse Breeders has no cause of quarrel, nor do we believe that its members have the slightest personal animosity against us or any member of our Committee; and our surprise was great that its Executive Committee should have been betrayed into fathering a document which reflects on us in a manner wholly unwarrantable. But when we remember that their Address is in reality a Wallace manifesto, and that $\mathrm{Mr}$. Wallace, who thinks that he has a grievance, has adroitly put forward the National Association to fight his battle, we need seek no further for an explanation of their conduct.

The Breeders' Trotting Stud Book was stated, in its prospectus as issued by us, to owe its origin to the manifest 
want that existed for an authoritative register on a scientific basis. The breeders in Kentucky have, for a long time, given much thought to a standard for the registration of trotting horses, and in October, I878, our numerous discussions on this subject culminated in a set of rules-sub. stantially those nuw before the public, the only difference being an amendment to Rule IV.

As practical men, we were guided in forming these rules by our own experience, and the experience of our neighbors and our fathers, in estimating the value of the running horse. Thorough-bred colts, by a speed-producing sire, out of a speed-producing dam, would sell in open market for ten and twenty times as much as colts by the same sire out of an untried or non-spced-producing dam, no matter how long her pedigree or by how many crosses she might run to the Godolphin Arabian. We believed that the true test of merit was not how much Messenger blood there might be in a trotting bred horse, but how much speed had been produced by his sire and by his dam. This is the fundamental principle on which our rules are based.

At the meeting of the National Association in November, I 878, a Kentucky member, to whom these rules had been submitted, called the attention of the Association to them. They had been previously sent to several gentlemen in New York. but no publicity had been before given to them. Not wishing to undertake the publication of a Stud Book ourselves, we tendered its compilatien, on the basis upon which we had settled, to $\mathrm{Mr}$. Wallace; but fearing a desire on his part to lower the standard, the offer was coupled with the condition that the rules should not be amended except by consent of a self-perpetuating Committee, composed of $i$. C. McDowell, R. S. Veecl, L. Brodhead, Charles Backman, and I. V. Baker, jr. Mr. Wallace declined the offer, but published the rules in the March number of his Monthly, spoke favorably of them; but, as a matter of course, he thought he could introduce material improvements. This 
he vainly attempted for several months. His efforts stimulated us in the same direction, and a proof-slip, containing a provisional set of rules (one of several of its kind which we had had struck), was sent to the members of our Committee and a few others for consideration, and with the object of exciting discussion and criticism. This was the proof that Mr. Wallace has led the public to believe was the standard adopted by us, and which has been called by him the "Pinafore Standard." This set of rules for admission was disapproved, in so far as it differed from that originally adopted, by all of our Committee and their associates as soon as submitted, and was never approved or adopted. That it did not constitute our standard was a'ell known to Mr. Wallace when he prepared and published his article on the "Pinafore Standard." And this is susceptible of easy demonstration.

Neither the proof-slip sent to Mr. Wallace in February, 1879, nor the "Pinafore" proof-slip contained the names of our Committee; nor was that Committee formed, named, or known, until just before the publication of our prospectus and rules as adopted. Now, the only source of information that Mr. Wallace could possibly have had, as to who composed our Committee, was the rules, as finally adopted, which were signed by that Committee, published in various papers, and sent to Mr. Wallace himself before the publication of his article; and yet that gentleman, in his "Pinafore" Editorial, names our Committee, which shows that he must have had before him the accepted standard of six rules, and then deliberately proceeds to quote the proofslip of seven rules which had never been given to the public, and which he knew had been rejected by us as our basis of registration, and to devote several pages to the ridicule of that which had no existence.

That Mr. Wallace should be guilty of such a mean deception was a surprise to us, and we have no doubt that it will be a surprise to the Executive Committee of the National 
Association that he has made them, in their Address, substantially reiterate this shameless misstatement. We regret sincerely the loss of respect that this occasions us to feel for Mr. Wallace. We felt compelled to allude to it because this article has created very generally a false impression as to our standard, and because it is only one of many misrepre. sentations in this Address, as we shall show.

And now, turning from the history of our undertaking to the criticisms of the National Association, we wish it, in the first place, distinctly understood that the impression sought to be made in its Address that we were indebted to Mr. Wallace or the National Association, for even so little as one thought that is contained in our standard, is false. On the contrary, the National Association has appropriated from our rules all that is good in theirs. Before this Association heard of our rules, neither it nor Mr. Wallace had the faintest conception of what should constitute a standard. A careful reading of the Association's organ (Wallace's Monthly) prior to November, 1878 , or even prior to the publication of our rules in it (March, 1879), will establish this fact. And, in like manner, we wish it as distinctly understood that we have never appropriated, never shall appropriate, and never intended to appropriate any of $\mathrm{Mr}$. Wallace's labor in the compilation of our Stud Book.

In the second place, our rules were framed without giving a thought to whose stock might or might not be eligible under them. The serious ground of complaint against them is, that the standard is too high, and that we "ostracise" some of the largest brecding cstalilishments in the country. Our answer is, that the horses embraced under this standard will fill a large volume; and as high as the standard is, it will include many animals that are not trotters. If large breeding establishments are ostracised, it is owing to the inferiority of their stock-not to the injustice of the rules; for in their application to our own stock, we have found that the animals which are ineligible are invariably the 
inferior ones, and the higher our estimation of an animal was before the determination of this standard, the greater now the number of rules under which it can claim entrance. Nor have we made one standard for our stock, and a different one for that of others. The same rules apply to the whole country. If our standard is not scientific, nay, is not the best that is adopted, it will not "ostracise" the stock of any one. It is folly to assert that, by a standard on an arbitrary basis, we could depreciate the stock of one man and enhance the value of that of another. If the National Association, or Mr. Wallace, or any one else, feels aggrieved at our action, they are at perfect liberty to make a set of rules and publish a Stud Book that will "ostracise" our stock.

IVe have published a set of rules which, in our judgment, and our judgment only, should govern registration in a Trotting Stud Book. We have not demanded that the public approve them, nor have we denounced or accused of pre. sumption any who disagree with us. We want one standard; some of the gentlemen in New York want another- $a$ lower standard. They have a perfect right to their opinion on this subject, and we claim the same right for ourselves.

We feel confident that the course of the National Association in characterizing our intention to publish a Trotting Stud Book a presumption, can meet with nothing but ridicule from even its most zealous partisans. Has the $\mathrm{Na}$ tional Association a legal or a moral copy-right on the compilation of Stud Books? On what, pray, does it base its claims to the exclusive right of compiling a Trotting Register? Is it on the score of its name? for, apart from this, it can lay no claim to a national character. Or is it on the score of its interest and success in the breeding of the trotting horse? We have no ambition to enter upon a discussion of the relative merits of any sections of the country in this business; but when, on a simple basis of facts, we compare Kentucky's position with that of the 
National Trotting Horse Breeders' Association, if either is to be accused of presumption, which shall it be?

Let us call the attention of our Eastern friends to the fact that Kentucky has been presumptuous enough to breed a two-year old with the best record (2:3I); a three-year old with the best record $(2: 231 / 2)$; a four-year old with the best record $(2: 193 / 4 ;)$ and a five-year old with the best record (2:18); and that we, the members of the Committee, are presumptuous enough to own more trotting horses eligible to entry, under the highest standard yet announced, than are owned by all the members of the National Breeders' Association combined; and we are presumptuous enough to believe that we have also bred more trotting horses, as measured by the 2:30 list, than have been bred by all the members of that Association combined. And these are some of the facts that lead us to presume that we know as nearly what standard is the best as Mr. Wallace, and that our interest in seeing the establishment of a just and scientific standard of registration is as lively as that of even the National Association.

But when we have eliminated the sin of presumption from out the list of our offenses as having too fictitious a basis to be entertained, and endeavor to get at some real ground of objection on the part of the New York Association to our standard, we find that $\mathrm{Mr}$. Wallace and his associates have abandoned the ferocity of their attack on all of our rules, with the exception of the VIth-the threecross rule. And since it is not possible for any intelligent individual to question the intrinsic merit of a regulation, the lowering of which would be but a signal for the admission of much of the veriest trash the country contains, Mr. Wallace, with exceeding bad taste, endeavors to excite odium against it by alleging that its disastrous result is to exclusively benefit Woodburn Farm, and particularly to "ostracise" General Withers and Mr. Backman. 
One of the strongest objections to our taking any notice of Mr. Wallace's pamphlet, as we have already said, was the necessity that was imposed on us of meeting him at times on his own ground, and we beg leave to apologize to Gen. Withers and Mr. Backman for referring to them thus particularly in a discussion which should be based on principles, not persons. Nor do we think that the bitter and rancorous attack on Woodburn should be passed over without notice by such of us as are not connected with that farm. Let us, first of all, then, in a general way, say that we regard Woodburn as by far our most formidable rival; but that we honor her, not only for the high standard of her stock, but for the high standard of fairness and integrity that has characterized all of her dealings, from the inception of the enterprise by the late R. A. Alexander to the present time; but that four rival breeding establishments, conducted by men past middle age, and who have had more than an average success in business enterprises, should spend their time and means to build up Woodburn, at the expense of their own establishments, is indeed remarkable. That such has not been our aim, will become still more evident when we begin to consider the application of our standard to Mr. Alexander's stock.

The three-cross rule (VI), which the New York Association so severely denounces, has always been regarded by us as the weakest of our six, and it was the subject of no little debate before its adoption. To provoke discussion among ourselves, our first proof-slips adopted the thorough-bred standard of five crosses; but in the end we unanimously settled on three, but also provided that, at a specified future date, the number should be increased. The Woodburn Catalogue for 1880 shows 85 animals, of which 53 are eligible under the rules as adopted by us, but only' 5 of these are dependent for entry on the three-cross nie-the rule denounced as gotten up exclusively for the benefit of Woodburn. Gen. Withers (Catalogue 1880) has 222 animals, 34 of which are 
eligible, and 25 of these are woholly dependent on the three-cross mile for admission. Mr. Backman (Catalogue 1878 , the last we have) has Iy 8 animals, 46 of which are eligible, and $3 \mathrm{r}$ of these are woholly dependent on the three cross mule for admission. Now, if the advancement of Woodburn and the ostracism of Fair Lawn and Stony Ford had been our object, let us see how we might have accomplished it. Had we stricken out the three-cross rule, or made it a five cross rule, Woodburn would have entered 48 animals out of her 85 ; Gen. Withers, 9 out of his 222; and Mr. Backman, 15 out of his I98. Have not the gentlemen in New York allowed Mr. Wallace to select for them the wrong rule by which to show Woodburn's supreme selfishness, and would it not have been safer for them to confine their attacks, in general terms, to the real and only grievance, to-wit: that the standard is tou high? Nay, moreover, if facts are of any interest to the New York Association, would it not be more appropriate, considering that, whereas Woodburn has only 53 animals which can be entered under our rules, Glen View can enter 75, to call this the "Glen View standard" rather than the Woodburn standard?

Before leaving this subject, we feel compelled to allude to a piece of very sharp practice on the part of the author of the Address. The catalogue of I879 of Woodburn shows that there were at Woodburn 86 , not 230 animals, as stated in the Address. In stating the number of animals owned by $\mathrm{Mr}$. Backman and Gen. Withers, the Address refers to them as so many animals at Stony Ford and Fair Lawn; in the case of Woodburn, by the use of the words, "the Catalogue shozes 230 animals," the impression is made, and that intentionally, that there were 230 animals at Woodburn. This number must have been obtained by embracing the produce under mares, including such as was shown to be sold, or by including the dams and sires in the pedigrees. The catalogue shows clearly that but 86 animals were at 
Woodburn. Would it not be advisable to appoint a Board of Censors to supervise the compilation of Addresses?

And now, glancing at some equally fictitious objections to our work, we find that the fact that we have no Board of Censors to superintend the compilation of our book, is made a ground of complaint in the Address. Our answer is, that the compilation of such a work is necessarily left to the Editor, and that the Board of Censors, appointed by the National Association, were mere figure-heads. Our Editor is restricted by certain clear and definite rules, founded on but one list (the 2:30), and that a well known one. But when we consider how voluminous and exceedingly complicated the rules of the National Association are, and that they require not only a 2:30 list, but a 2:35 list to wagon, and a $2: 40$ list, a thing which has no real or probable existence, we are surprised that the National Association, if its object is to produce a reliable work, does not institute an arny instead of a Board of Censors. Surely it is astonishing how much cumbersome rubbish was attached to our rules in their modification and amplification before their adoption by the National Association.

There is one other point of difference to which the Address invites attention. The National Breeders' Association requires a record won under the rule of National Trotting Association.

Which rule is as follows:

"Any contest for premium, purse, stake, or wager on any "course, and in the presence of a judge or judges, shall "constitute a public race."

The time made in a public race is a record.

Our provision in regard to certificates is as follows:

"A public trial, trotted according to the rules of the National Trotting Association for governing races, and timed by three judges, selected in the usual way by any Association, a member in good standing of the National Trotting Association, shall be considered a record so far as eligibility to entry in this stud Book is concerned. A certificate, giving the time made under the above conditions, must be signed by the three 
judges and countersigned by the President and Secretary of the Associa. tion authorizing said trial; such certificate to accompany the entry, and remain on file."

It is only necessary to quote these rules to show how much better guarded our trial is from fraudulent practices than is the technical record.

That an Association which pretends to be so violently opposed to betting, should cling to the dogma that a wager is the only test of honesty, is surprising. It is evident that the gentlemen are a little ashamed of this, for they proceed in their address to say:

"In insisting upon a technical record, your Committee " acted more with reference to the present than the future. “* * * * * * * There will be ample time to con"sider and determine whether it is desirable to admit a pub. "lic trial in lieu of the technical record." (Think of that!) * * * * "If such trials are allowed, they will have to "take place under the jurisdiction and control of this Asso. "ciation." * * * * * * * * * *

When we consider that this Association neither owns nor controls one single track in the whole land, we catch its drift. It must be a jurisdiction and control in a Pickwickian sense that is meant.

In conclusion, we will state that, whether or not we published a Stud Book, the evil-if it is an evil-that inuch stock is "ostracised" has already been accomplished by the publication of the two sets of rules, and the discussion that has been caused thereby. The public has learned how the value of trotting horses is estimated by practical men, and the lesson will not be forgotten. That some good may also be the result, a Stud Book will be compiled and published under the rules as announced by us; and in order to make this book complete, all eligible animals, whose pedigrees can be established, will be recorded ivithout fee. 
Mr. Le Grand Lucas, finding that the work, on the scale now proposed, would require too much of his time to properly inform himself, has asked to be relieved.

Mr. F. H. Sanders, the Editor of the "Chicrgo Live Stock Foumal," will compile and edit the work, and communications on the subject should be addressed to him at the "Lakeside Building, Chicago, Illinois."

A. J. ALEXANDER, of Woodbum,

R. WEST, of Edge Hill,

J. C. McFERRAN, of Glen View,

R. S. VEECH, of Indian Hill,

H. C. McDOWELL, of Woodlake,

L. BRODHEAD, of Woodburn,

Committee on Rules. 


\section{A P PENDIX.}

\section{Rules for Entry in the Breeders' Trotting Stud Book.}

The object of this book is to preserve a reliable record of the pedigrees of all trotting horses that have trotted a mile in two minutes and thirty seconds $(2: 30)$ or better; or that trace, directly or collaterally, to such horses under the conditions hereinafter mentioned.

Harness, team or saddle records of $2: 30$ or better, will entitle animals to entry.

Any animal coming within the provisions of any of the following rules will be entitled to entry:

RulE I. Any stallion, mare, or gelding that has a record of two minutes and thirty seconds $(2: 30)$ or better.

Rule II. Any stallion that has sired a horse, mare, or gelding with a record of two minutes and thirty seconds $(2: 30)$ or better.

RULE III. Any mare that has produced a horse, mare, or gelding with a record of two minutes and thirty seconds $(2: 30)$ or better.

RULE IV. Any mare, the dam of any stallion or mare that has sired or produced a horse, mare, or gelding with a record of two minutes and thirty seconds $(2: 30)$ or better; provided said mare was by a stallion or out of a mare entered in this book.

RULE V. Any animal by a stallion, entered in this Stud Book, out of a mare entered therein.

RULE VI. Any animal whose sire and whose first and second dams' sires are entered in this Stud Book. 


\section{Rules for Entry in the National Association of Trotting Horse Breeders' Stud Book.}

In order to define what constitutes a trotting-bred horse, and to establish a BREED of trotters on a more intelligent basis, the following rules are adopted to control admission to the records of pedigrees. When an animal meets the requirements of admission, and is duly registered, it shall be accepted as a standard trotting-bred animal.

First.-Any stallion that has, himself, a record of two minutes and thirty seconds $\left(2: 3^{\circ}\right)$ or better; provided any of his get has a record of $2: 40 \mathrm{or}$ better; or, provided his sire or dam, his grandsire or his grandam, is already a standard animal.

Second.-Any mare or gelding that has a record of 2:30 or better.

Third.-Any horse that is the sire of two animals with a record of $2: 30$ or better.

Fourth. - Any horse that is the sire of one animal with a record of 2:30 or better; provided he has either of the following additional qualifications :

I. A record, himself, of 2:40 or better.

2. Is the sire of two other animals with a record of $2: 40$ or better.

3. Has a sire or dam, grandsire or grandam, that is already a standard animal.

Fifth. - Any mare that has produced an animal with a record of $2: 30$ or better.

Sixth.-The progeny of a standard horse when out of a standard mare.

Seventh.-The progeny of a standard horse when out of a mare by a standard horse.

Eighth.-The progeny of a standard horse when out of a mare whose dam is a standard mare.

Ninth.-Any mare that has a record of 2:40 or better, and whose sire or dam, grandsire or grandam, is a standard animal.

Tenth.-A record to wagon of $2: 35$ or better shall be regarded as equal to a $2: 30$ record. 


